\title{
THE EFFECT OF PHOSPHORUS METABOLISM ON THE MOTION OF SACCHAROMYCES CEREVISIAE VOLUTIN GRANULES
}

\author{
M.S. Kharchuk, E.N. Gromozova \\ Zabolotny Institute of Microbiology and Virology, NAS of Ukraine, \\ 154 Acad. Zabolotny Str., Kyiv, 03143, Ukraine \\ e-mail:sithmcx@ukr.net
}

\begin{abstract}
It is known that moving volutin granules ("dancing bodies"), mechanism of which occurrence remains poorly understood, can be observed in yeast vacuoles. This study was performed to reveal the presence of a connection between moving volutin granules of Saccharomyces cerevisiae and polyphosphate metabolism in conditions of phosphoric starvation and hypercompensation. Methods. Cytological, biochemical, statistical methods were used in the study. Results. It was observed that the inactivation of the PPN1 gene, which encodes exopolyphosphatase Ppn1, resulted in a change in the number of cells with moving volutin granules ("dancing bodies" index) in the studied conditions. The index of "dancing bodies" was almost always lower in mutant CRN strain than in parent CRY strain. Using linear correlation analysis and factor analysis with the method of principal component, it was established that the "dancing bodies" index in both strains had significant correlation coefficients with exopolyphosphatase activity (EPPA) and the content of polyphosphate fractions (polyP). The difference was that this index in parent strain correlated better with the first three fractions of inorganic polyphosphates, while in mutant strain - with polyP4 and EPPA. Conclusions. Obtained data indicated the direct connection of motion of volutin granules with phosphoric metabolism in the studied conditions. It is assumed that the phenomenon of "dancing bodies" may be a consequence of the activity of vacuolar polyphosphatases.
\end{abstract} ules.

Keywords: yeasts, inorganic polyphosphates, exopolyphosphatases, "dancing bodies", volutin gran-

Volutin granules (Babes-Ernst bodies, metachromatic or polyphosphate granules) are an accumulation of inorganic polyphosphates in a complex with metal cations, proteins, and, possibly, other organic compounds [1]. They are observed as electron-dense bodies in transmission electron microscopy [1,2], give a positive metachromatic reaction in staining thiazine dyes [1-3], have stable bright yellow-green fluorescence in the case of 4,6'-diamidino-2-phenylindole (DAPI) using $[1,2,4]$. Also, they are inherent in an active motion in vacuoles of yeast cells, which is known as "dancing bodies" in the literature [5-10]. It is believed that the moving of volutin granules have Brownian nature $[4,8,10]$. However, there is indirect evidence that "dancing bodies" may be a consequence of active biologic processes [7, 11-16]. Moving volutin granules were observed in aging cells culture $[7,11]$. "Dancing bodies" appeared in a significant number of yeast cells under sublethal doses of occidiofungin, which is an antibiotic resulting in apoptosis [12]. Their motion stopped at the moment of the termination of mitochondrial activity during the development of spontaneous apoptosis [13]. We had noted that maximal motility of volutin granules was observed in the optimal temperature and $\mathrm{pH}$ of the medium conditions for yeast growth. It was also found that electromagnetic radiation of radiofrequency range (40.68 MHz, $30 \mathrm{~W}, 30 \mathrm{~min}$ ) reduced dramatically the percentage of cells with "dancing bodies" [14]. It was shown that the phenomenon of motility of volutin granules was rhythmic in nature. This rhythm was similar in S. cerevisiae UCM Y-517 and CRY strains, which were without defects in phosphorus metabolism. At the same time, the rhythm of $S$. cerevisiae CNX strain, which was defective in exopolyphosphatases Ppx1 and Ppn1, somewhat differed from the parental $S$. cerevisiae CRY strain. The rhythm of the "dancing bodies" index was also observed as a coincidence with the rhythm of galactic cosmic rays in about 9 days [15]. The possible participation of exopolyphosphatase activity in the motility of volutin granules was evidenced by a positive correlation between these indexes obtained with 
different stress effects on cells [16].

Considering the above-mentioned facts, the purpose of this work was to establish the presence of a relation between the motility of volutin granules of Saccharomyces cerevisiae and polyphosphate metabolism under conditions of phosphorus starvation and hypercompensation.

Materials and methods. In this work, we used strains of the yeast $S$. cerevisiae, which were kindly provided by the researchers of Skryabin Institute of Biochemistry and Physiology of Microorganisms of RAS: CRN is a mutant strain for the PPN1 gene: unable to synthesize exopolyphosphatase Ppn1 and has the genotype MATa ade2 his 3 ura3 ppn 1D [17]; $\mathrm{CRY}$ is its parental strain, which has the genotype MATa his3 ura3 leu2 trp1 ade2 [18].

Yeast strains were cultivated in $200 \mathrm{~mL}$ of the nutrient medium under thermostatic conditions $\left(28^{\circ} \mathrm{C}\right)$ with constant stirring $(257 \mathrm{rpm})$ in $750 \mathrm{~mL}$ flasks for $24 \mathrm{~h}$. The cultures were initially grown on a complete Reeder medium (g/L: $\left(\mathrm{NH}_{4}\right)_{2} \mathrm{SO}_{4}-3$; $\mathrm{MgSO}_{4}-0.7 ; \mathrm{NaCl}-0.5 ; \mathrm{KH}_{2} \mathrm{PO}_{4}-1 ; \mathrm{K}_{2} \mathrm{HPO}_{4}$ 0.1 ; yeast extract -2 ; glucose -10 ). After that, the cells were transferred to Reeder medium without phosphorus (g/L: $\left(\mathrm{NH}_{4}\right)_{2} \mathrm{SO}_{4}-3 ; \mathrm{MgSO}_{4}-$ $0.7 ; \mathrm{NaCl}-0.5$; glucose - 10). After starvation of phosphorus, the yeast was again placed on a complete Reeder nutrient medium. The cells were previously sedimented by centrifugation at $2000 \mathrm{rpm}$ for $2 \mathrm{~min}$ before each transfer to a fresh medium. The sediment was washed twice with distilled water. Samples at each stage of cultivation were analyzed after 4, 8, 18, and $24 \mathrm{~h}$.

The number of cells with moving volutin granules ("dancing bodies" index) was counted using fluorescence microscopy (Ulab LW300TF microscope, Ulab, China) and the vital fluorescent dye DAPI (Sigma, USA) at a final concentration of $5 \mathrm{mg} / \mathrm{L}$ [4]. We took into account the cells that contained both moving and unmoving volutin granules, which were characterized by stable bright yellow fluorescence. "Dancing bodies" index was expressed as a percentage of the total number of cells with volutin granules in the population.

Exopolyphosphatase activity (EPPA) was determined by the formation of the amount of orthophosphoric acid. The reaction mixture from calculation per $1 \mathrm{~mL}$ contained $100 \mu \mathrm{L}$ of cell homogenate and $900 \mu \mathrm{L}$ of aqueous $50 \mathrm{mM}$ Tris$\mathrm{HCl}$ buffer (pH 7.2) with $2.5 \mathrm{mM} \mathrm{MgSO}_{4}$ and $50 \mu \mathrm{M}$ inorganic polyphosphate with an average chain length of 200 phosphate residues. The reaction mixture was incubated for $30 \mathrm{~min}$ at
$28{ }^{\circ} \mathrm{C}$. The unit of activity (U) was the amount of the enzyme that forms $1 \mu \mathrm{mol}$ of orthophosphoric acid in $1 \mathrm{~min}$ [19].

Five fractions of inorganic polyphosphates were extracted stepwise from $100 \mathrm{mg}$ of crude biomass according to the method of Liss and Langen [20] modified by Kulaev et al. [21]. This method allows to obtain five fractions of inorganic polyphosphates from yeast cells: acid-soluble (polyP1, extraction with $0.5 \mathrm{~N} \mathrm{HClO}_{4}$ at $0{ }^{\circ} \mathrm{C}$ ), salt-soluble (polyP2, extraction with saturated $\mathrm{NaClO}_{4}$ solution at $0^{\circ} \mathrm{C}$ ), soluble in a weak alkali (polyP3, extraction with $\mathrm{NaOH}$ solution, $\mathrm{pH} 9-10$, at $0{ }^{\circ} \mathrm{C}$ ), soluble in a strong alkali (polyP4, extraction with $0.05 \mathrm{~N} \mathrm{NaOH}$ at $0{ }^{\circ} \mathrm{C}$ ) and hot perchloric acid extract (polyP5, the polyphosphate content was determined from the amount of Pi released after the residual biomass was treated with $0.5 \mathrm{~N} \mathrm{HClO}_{4}$ at $90{ }^{\circ} \mathrm{C}$ for $20 \mathrm{~min}$ ). The obtained extracts of polyphosphate fractions were brought to an equal volume with distilled water. The first four fractions of inorganic polyphosphates were hydrolyzed in $1 \mathrm{M} \mathrm{HCl}$ at $100^{\circ} \mathrm{C}$ for $15 \mathrm{~min}$ (hydrolysis of the fifth polyphosphate fraction was already carried out during its extraction). The unit of the amount of the polyphosphate fraction in the cells was accepted as the amount of the formed orthophosphate per $1 \mathrm{mg}$ of the protein obtained from the initial biomass.

The amount of orthophosphate was determined colorimetrically using a photoelectric colorimeter at a wavelength of $750 \mathrm{~nm}$ and a cuvette with $0.5 \mathrm{~cm}$ optical path length, as well as a calibration graph. Reagent A (an aqueous solution of $2 \%$ sulfuric acid containing $0.5 \%$ ammonium molybdate and $0.5 \%$ sodium dodecyl sulfate $)$ and reagent B (10\% aqueous solution of ascorbic acid) were used for the determination of orthophosphoric acid in a sample. Reagents A and B were mixed in a ratio of 100:1, respectively. The resulting mixture was added to the samples in a ratio of 2:1 (reagent AB:sample) and incubated for $10 \mathrm{~min}$ at $28^{\circ} \mathrm{C}$ [1].

Protein concentration was determined by the Bradford protein assay [22]. Bovine serum albumin was the standard.

The data obtained were statistically processed using the software Statistica 10 (StatSoft Inc., 2011) by linear correlation analysis with $p<0.05$ and factor analysis by the principal component method with a significant load of Pearson's coefficient $R \geq 0.7$.

Results. According to the literature [17, 19, 23], strains with an inactivated PPN1 gene earlier reach the stationary stage of growth (approx. 16-18 h of 
cultivation) compared to the parent strain (approx. 20-22 h of cultivation). Therefore, in our studies, $24 \mathrm{~h}$ of cultivation for the parental CRY strain and the mutant CRN strain were the beginning and middle of the stationary growth stage, respectively.

It was shown that the number of cells with moving volutin granules under the studied conditions differed in both strains. "Dancing bodies" index of the mutant CRN strain, in which gene encoding exopolyphosphatase Ppn 1 is inactivated, was almost always lower than in the parental CRY strain (Fig. 1). There were also differences in the dynamics of this index in both strains. Under normal phosphorus supply, the number of cells with moving volutin granules in the CRY strain decreased (approx. 2.2 times) in $18 \mathrm{~h}$ of growth, after which it increased again. In the CRN mutant strain, the "dancing bodies" index rapidly increased in $4 \mathrm{~h}$ of growth (approx. 5.3 times) compared to the initial value, after which it rapidly decreased (3 times). Subsequently, the number of cells with moving volutin granules decreased gradually. During phosphorus starvation in the CRY strain, the "dancing bodies" index rapidly decreased (approx. 4.5 times) already in $8 \mathrm{~h}$ of cultivation (Fig. 1). In contrast to the parental strain, the number of cells with moving volutin granules in the CRN mutant strain in $8 \mathrm{~h}$ of phosphorus starvation, on the contrary, increased (approx. 2.4 times) (Fig. 1). Later, the "dancing bodies" index decreased as in the parental strain. During phosphorus hypercompensation, both strains showed a rapid increase in the number of cells with moving volutin granules in $4 \mathrm{~h}$ of cultivation (Fig. 1). Subsequently, there was a decrease in the "dancing bodies" index, but at a different rate for each strain: it was gradual in the parent, while it was rapid in the mutant.

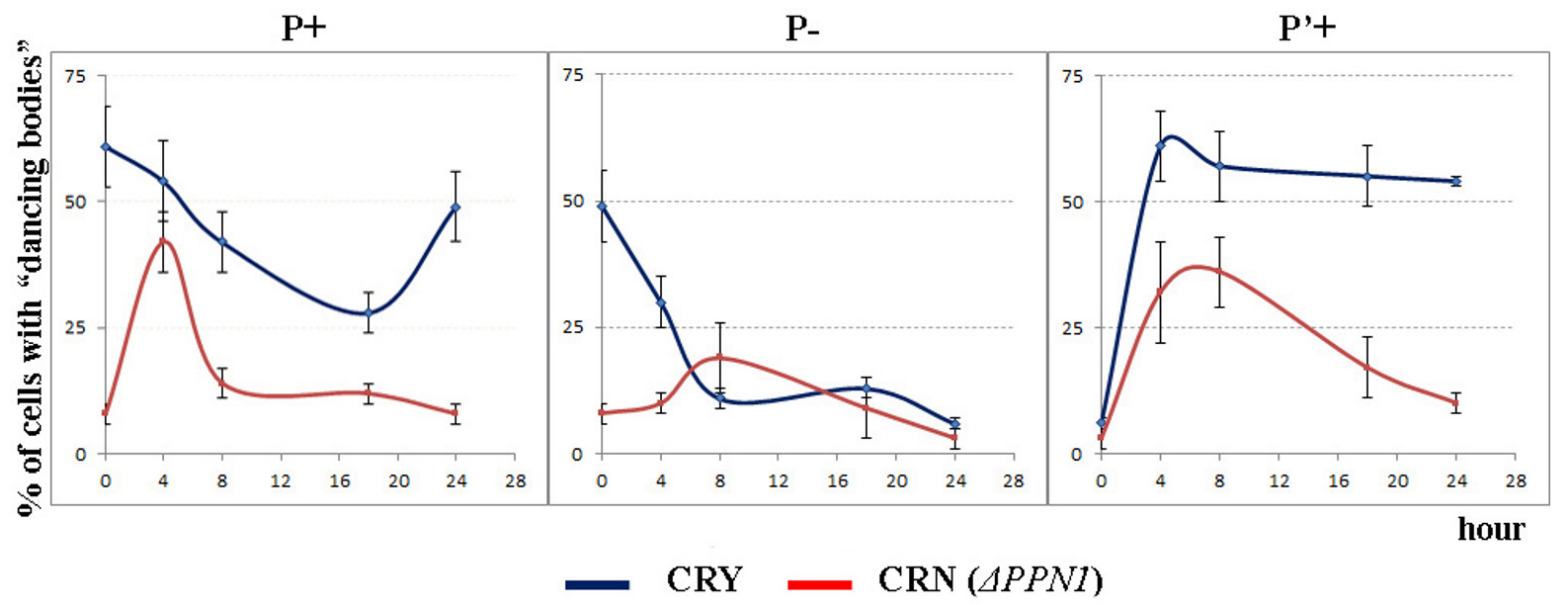

F i g. 1. The number of $S$. cerevisiae cells with moving volutin granules in strains CRY (parental) and CRN (mutant with inactivated PPN1 gene) under conditions of normal cell phosphorus supply $(\mathrm{P}+)$, phosphorus starvation $(\mathrm{P}-)$, and hypercompensation $\left(\mathrm{P}^{\prime}+\right)$

It is known that inorganic polyphosphates are the main component of volutin granules [1]. Few data indicate that the composition of volutin granules of different organisms may include polyphosphate fractions polyP1, polyP2, and polyP3 [3, 24-26]. It was shown that the dynamics of the total amount of inorganic polyphosphates under the studied conditions had the same tendency in both strains (Fig. 2, 3). The difference was that inactivation of the PPN1 gene led to a greater increase in the content (approx. 1.7 times) of these polymers in 8 $\mathrm{h}$ of hypercompensation in the mutant CRN strain than in the parental CRY strain. This is consistent with the literature data [23]. Significant differences in the content of polyphosphate fractions of polyP1, polyP2, and polyP3 (Fig. 2, 3) were observed for both strains under the studied conditions. However, there were also common features in changes in the number of polyphosphate fractions. During phosphorus starvation, the amount of polyP1, polyP2, and polyP3 rapidly decreased in both strains. The fractions of polyP4 and polyP5 were practically unchanged, remaining at the same low level. In 4 hours of hypercompensation, a rapid accumulation of polyphosphates of the first three polyphosphate fractions occurred in both the parental CRY strain and the mutant CRN strain. At the same time, the amount of polyP4 and polyP5 slightly increased, and in the last polyphosphate fraction, this occurred in $24 \mathrm{~h}$ of cultivation. Taking into account the noticeable changes in the studied conditions in the first three polyphosphate 
fractions, the results obtained probably may indicate that inorganic polyphosphates of volutin granules are actively involved in the metabolism of these polymers. In turn, such activity can indirectly or directly lead to the appearance of "dancing bodies".

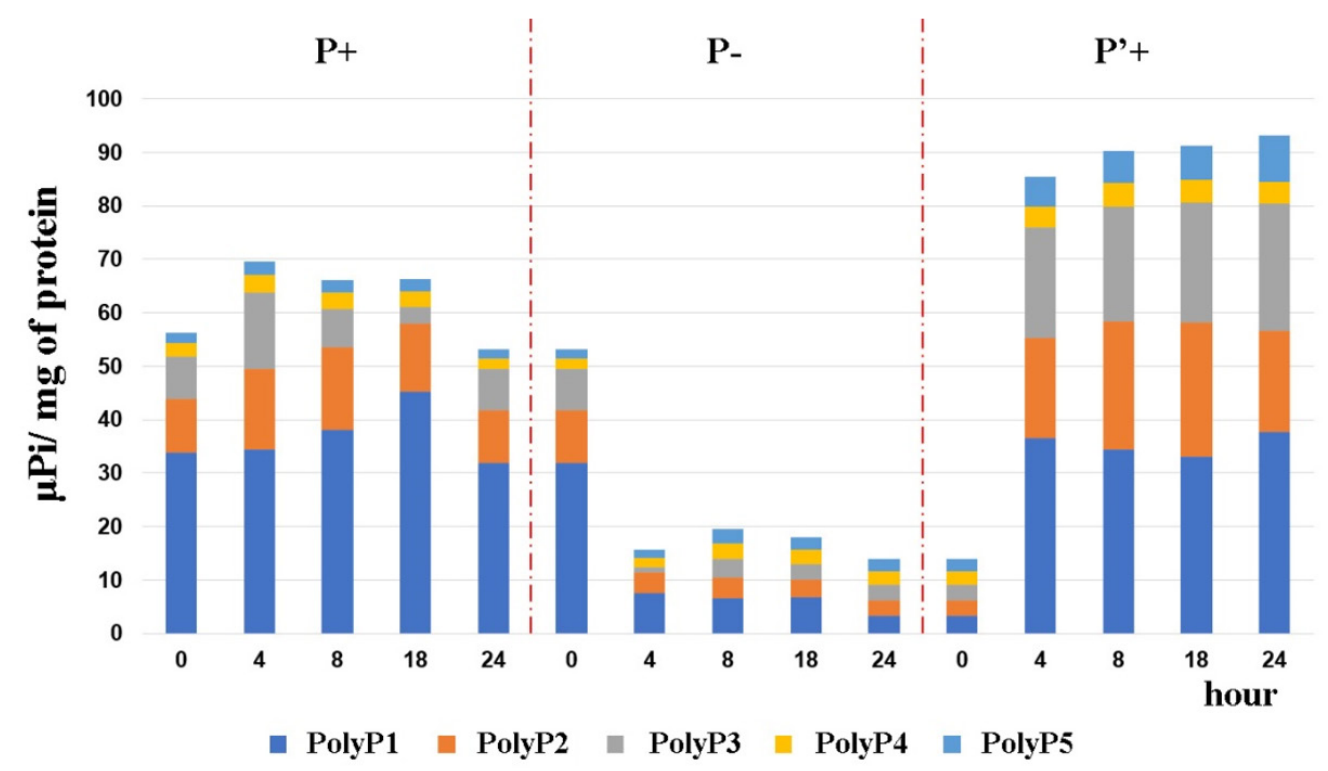

F i g. 2. The content of the total amount of inorganic polyphosphates and their fractions in $S$. cerevisiae CRY yeast cells under conditions of normal phosphorus supply $(\mathrm{P}+)$, phosphorus starvation $(\mathrm{P}-)$, and hypercompensation $\left(\mathrm{P}^{\prime}+\right)$

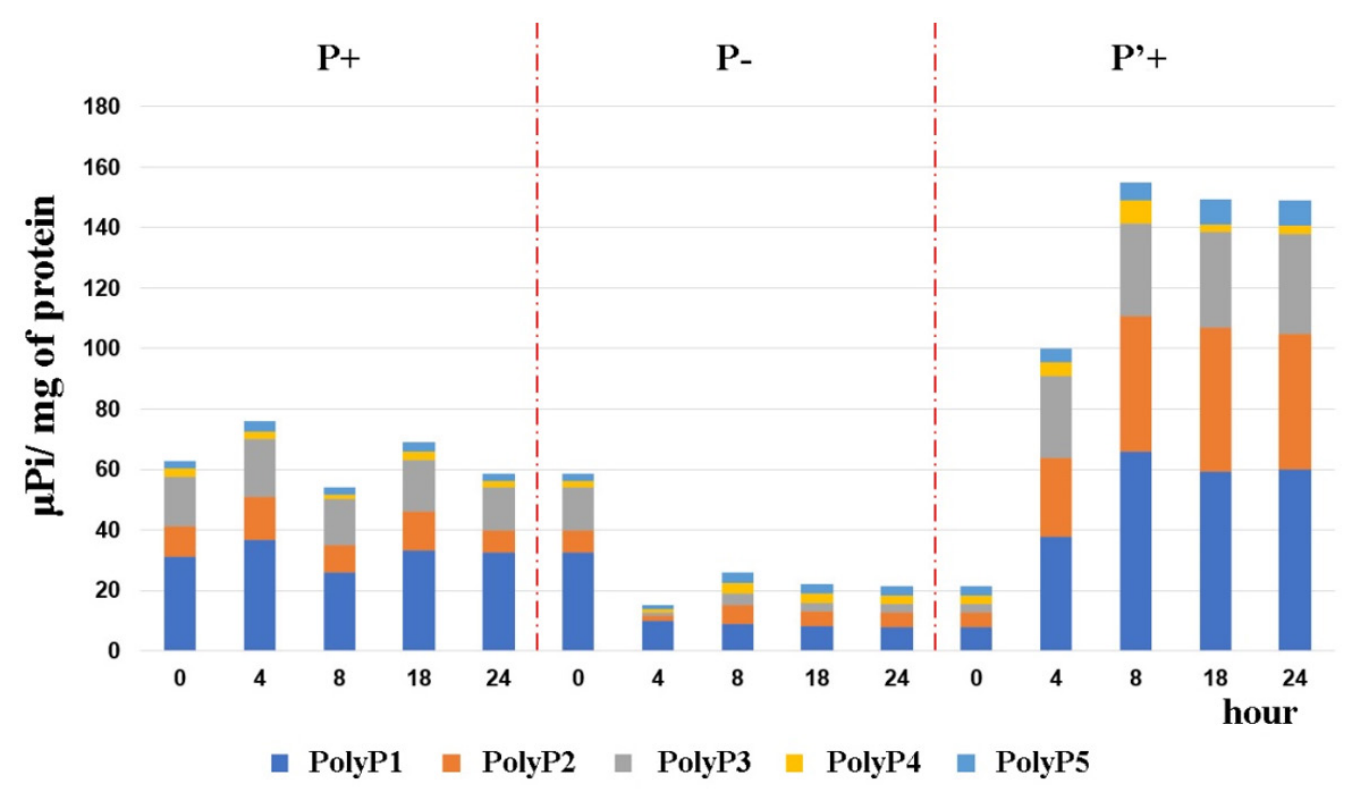

F i g. 3. The content of the total amount of inorganic polyphosphates and their fractions in $S$. cerevisiae $C R N$ yeast cells under conditions of normal phosphorus supply $(\mathrm{P}+)$, phosphorus starvation $(\mathrm{P}-)$, and hypercompensation $\left(\mathrm{P}^{\prime}+\right)$

Considering the significant contribution of exopolyphosphatases in the metabolism of inorganic polyphosphates of the yeast $S$. cerevisiae $[1,27]$ and their probable participation in the motility of volutin granules [16], the change in the total EPPA was studied. It was found that the dynamics of total EPPA for both strains were almost asynchronous (Fig. 4), which is consistent with the literature data [27]. It should be noted that the total EPPA values for both strains under the studied conditions to some extent corresponded to the changes in the "dancing bodies" index. This possibly indicates that exopolyphosphatases may participate in the motion of volutin granules, which is consistent with our previous data [16]. 


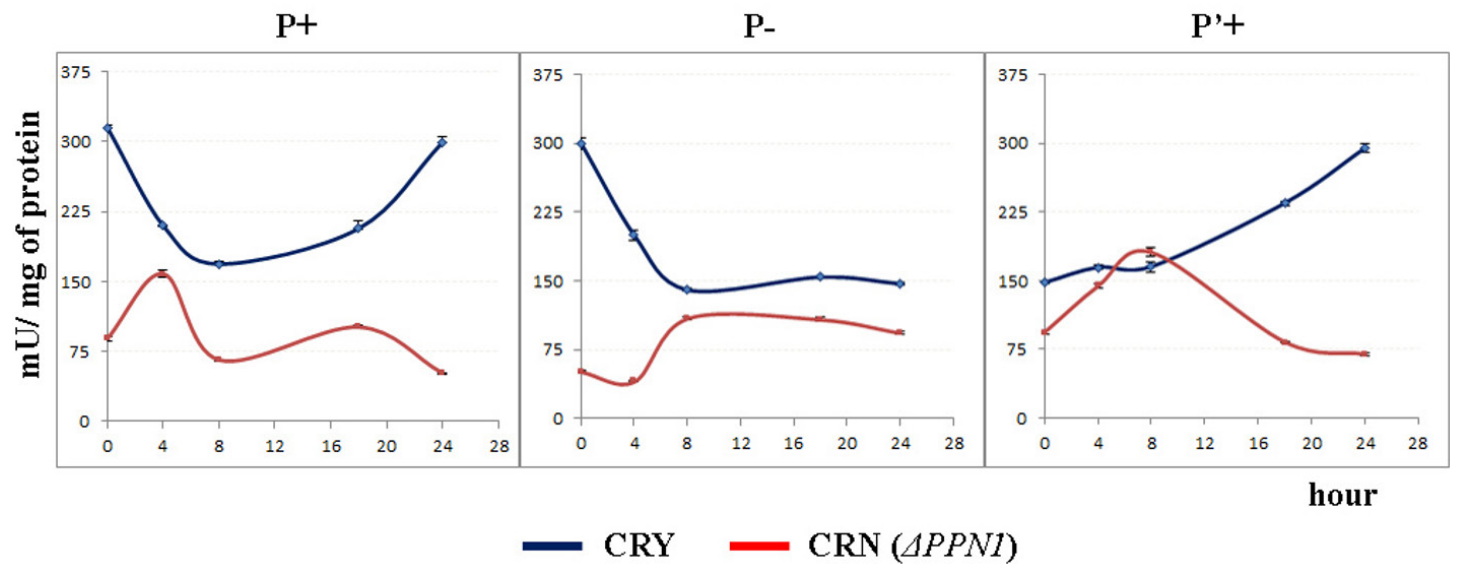

F i g. 4. Total exopolyphosphatase activity in strains CRY (parental) and CRN (mutant with inactivated PPN1 gene) under conditions of normal phosphorus supply $(\mathrm{P}+)$, phosphorus starvation $\left(\mathrm{P}_{-}\right)$, and hypercompensation $\left(\mathrm{P}^{\prime}+\right)$

Using linear correlation analysis, it was found that the "dancing bodies" index in the parent strain significantly correlated with the total EPPA and the content of polyphosphate fractions of polyP1, polyP2, and polyP3 (Table 1). This is consistent with the literature data about these fractions in volutin granules [3, 24-26]. At the same time, the number of cells with moving volutin granules in the mutant strain had a significant connection with total EPPA and PolyP4 (Table 2). This result may indicate that the inactivation of the PPN1 gene may affect the polyphosphate composition of volutin granules. This, to some extent, confirms the participation of phosphorus metabolism in the phenomenon of "dancing bodies".

\section{Table 1}

Correlations between the studied parameters, obtained by linear correlation analysis $(p<0.05)$, in the $S$. cerevisiae CRY (parental) strain

\begin{tabular}{|c|c|c|c|c|c|c|c|}
\hline & DB & EPPA & PolyP1 & PolyP2 & PolyP3 & PolyP4 & PolyP5 \\
\hline DB & 1.00 & 0.58* & $0.78^{*}$ & $0.79 *$ & $0.76^{*}$ & 0.49 & 0.49 \\
\hline EPPA & 0.58* & 1.00 & 0.47 & 0.22 & 0.25 & -0.09 & 0.14 \\
\hline PolyP1 & $0.78 *$ & 0.47 & 1.00 & $0.78 *$ & $0.57 *$ & 0.50 & 0.39 \\
\hline PolyP2 & $0.79 *$ & 0.22 & $0.78^{*}$ & 1.00 & 0.90 & $0.86^{*}$ & $0.75^{*}$ \\
\hline PolyP3 & $0.76^{*}$ & 0.25 & $0.57 *$ & 0.90* & 1.00 & $0.89 *$ & 0.90* \\
\hline PolyP4 & 0.49 & -0.09 & 0.50 & $0.86^{*}$ & $0.89 *$ & 1.00 & 0.89* \\
\hline PolyP5 & 0.49 & 0.14 & 0.39 & $0.75^{*}$ & $0.90 *$ & 0.89* & 1.00 \\
\hline
\end{tabular}

Legend: * - statistically significant correlations at $p<0.05, \mathrm{DB}-$ "dancing bodies" index, EPPA - exopolyphosphatase activity, PolyPn - polyphosphate fraction.

Table 2

Correlations between the studied parameters in $S$. cerevisiae CRN ( $\triangle P P N 1)$ strain, obtained by linear correlation analysis $(p<0.05)$

\begin{tabular}{|l|c|c|c|c|c|c|c|}
\hline & DB & EPPA & PolyP1 & PolyP2 & PolyP3 & PolyP4 & PolyP5 \\
\hline DB & 1.00 & $\mathbf{0 . 8 2 *}$ & 0.44 & 0.39 & 0.47 & $\mathbf{0 . 5 9 *}$ & 0.21 \\
\hline EPPA & $\mathbf{0 . 8 2 *}$ & 1.00 & 0.32 & 0.33 & 0.34 & $\mathbf{0 . 8 1}^{*}$ & 0.21 \\
\hline PolyP1 & 0.44 & 0.32 & 1.00 & $\mathbf{0 . 9 2}^{*}$ & $\mathbf{0 . 9 7}^{*}$ & 0.49 & $\mathbf{0 . 7 8}^{*}$ \\
\hline PolyP2 & 0.39 & 0.33 & $\mathbf{0 . 9 2 *}$ & 1.00 & $\mathbf{0 . 9 1 *}$ & 0.54 & $\mathbf{0 . 9 4}^{*}$ \\
\hline PolyP3 & 0.47 & 0.34 & $\mathbf{0 . 9 7}^{*}$ & $\mathbf{0 . 9 1}^{*}$ & 1.00 & 0.47 & $\mathbf{0 . 7 9 *}$ \\
\hline PolyP4 & $\mathbf{0 . 5 9}^{*}$ & $\mathbf{0 . 8 1 *}$ & 0.49 & 0.54 & 0.47 & 1.00 & 0.40 \\
\hline PolyP5 & 0.21 & 0.21 & $\mathbf{0 . 7 8 *}$ & $\mathbf{0 . 9 4}^{*}$ & $\mathbf{0 . 7 9 *}$ & 0.40 & 1.00 \\
\hline
\end{tabular}

Legend: *- statistically significant correlations at $p<0.05, \mathrm{DB}-$ "dancing bodies" index, EPPA - exopolyphosphatase activity, PolyPn - polyphosphate fraction. 
According to the results obtained by factor analysis with the principal component method, the most significant correlation coefficients by the main factor 1 in the parental CRY strain were observed between the number of cells with moving volutin granules and all polyphosphate fractions, while their significant values in the CRN mutant strain marked between all studied parameters (Table 3). For the main factor 2, the significant coefficients in the parental CRY strain were noted between the "dancing bodies" index, EPPA, polyP4, and
polyP5. At the same time, a correlation with significant coefficients in the CRN mutant strain was observed between the "dancing bodies" index, EPPA, and polyP4 (Table 3). Considering the obtained results of factor analysis, we assume that the main factor 1 reflects the process of synthesis of inorganic polyphosphates, while the main factor 2 is their degradation. Thus, both synthesis and degradation of inorganic polyphosphates may play a role in the appearance of the phenomenon of "dancing bodies".

Table 3

Correlations between the studied parameters in two $S$. cerevisiae strains, obtained by factor analysis with a principal component method

\begin{tabular}{|l|c|c|c|c|}
\hline \multirow{2}{*}{} & \multicolumn{2}{|c|}{ CRY (parental) } & \multicolumn{2}{c|}{ CRN $(\Delta P P N 1)$} \\
\cline { 2 - 5 } & Factor 1 & Factor 2 & Factor 1 & Factor 2 \\
\hline EPPA & $\mathbf{- 0 . 8 1 *}$ & $\mathbf{0 . 4 0 * *}$ & $\mathbf{- 0 . 5 6 * *}$ & $\mathbf{- 0 . 5 9 * *}$ \\
\hline PolyP1 & -0.33 & $\mathbf{0 . 6 4 * *}$ & $\mathbf{- 0 . 5 3 * *}$ & $\mathbf{- 0 . 7 7 *}$ \\
\hline PolyP2 & $\mathbf{- 0 . 7 7 *}$ & $\mathbf{0 . 4 1 * *}$ & $\mathbf{- 0 . 9 1 *}$ & 0.21 \\
\hline PolyP3 & $\mathbf{- 0 . 9 4 *}$ & -0.06 & $\mathbf{- 0 . 9 3 *}$ & 0.24 \\
\hline PolyP4 & $\mathbf{- 0 . 9 2 *}$ & -0.19 & $\mathbf{- 0 . 9 1 *}$ & 0.19 \\
\hline PolyP5 & $\mathbf{- 0 . 8 3 *}$ & $\mathbf{- 0 . 4 9 * *}$ & $\mathbf{- 0 . 6 5 * *}$ & $\mathbf{- 0 . 5 0 * *}$ \\
\hline Prp.Totl*** & $\mathbf{- 0 . 7 9 *}$ & $\mathbf{- 0 . 3 9 * *}$ & $\mathbf{- 0 . 8 1 *}$ & 0.34 \\
\hline
\end{tabular}

Legend: * - statistically reliable correlations with marked loadings are $>0.7, * *$ - significant correlations with marked loadings are $<0.70, * * *$ - the percentage of explained variance, DB - "dancing bodies" index, EPPA - exopolyphosphatase activity, PolyPn - polyphosphate fraction.

Discussion. In this study, we found a significant correlation of the "dancing bodies" index with both changes in the content of inorganic polyphosphates and EPPA. This is consistent with our previous results, where a connection was noted between the motion of volutin granules and phosphorus metabolism $[15,16]$.

It is known that the total content of inorganic polyphosphates and their distribution by fractions in cells of different organisms can vary greatly depending on the stage of development [2834]. The noticeable quantitative and qualitative changes of the composition of these polymers were observed in the tissues of the brain and liver of embryos, newborns, adult and old rats [28]. The content of inorganic polyphosphates rapidly decreased during the hatching of gemmules in the freshwater sponges Ephydatia muelleri, after which their amount increased to a maximum value [29]. Long-chain inorganic polyphosphates were found in plasmodia and cysts of the slime mold Physarum polycephalum, while during sporulation they were degraded into short-chain polymers [30]. During embryogenesis in the eggs of the bug Rhodnius prolixus, the content of inorganic polyphosphates decreased and reached minimum value in the hatching of the larva [31]. Rapid decrease in the amount of these polymers was observed under normal phosphorus supply of $S$. cerevisiae cells during the depletion of glucose in the medium, after which their amount at the stationary stage was again restored to the level that was in the culture at the beginning of growth. The changes in the content for each fraction of inorganic polyphosphates under these conditions were also observed [32]. The amount of these polymers reached a minimum during phosphorus starvation in $S$. cerevisiae yeast cells, while there was a rapid accumulation of inorganic polyphosphates during several hours of cultivation under hypercompensation [33-34]. These literature data are to some extent consistent with our results. Probably, a change in the number of cells with moving volutin granules in the yeast population can be associated with the fluctuation of the content of some fraction of inorganic polyphosphates. Previously, we observed a significant correlation of the "dancing bodies" index with the polyphosphate fraction of polyP1 under various stresses [16]. In this study, a linear correlation analysis showed the 
presence of a connection between the amount of cells with moving volutin granules with the first three polyphosphate fractions in the parental CRY strain, which is consistent with literature data $[3,24-26]$. At the same time, such correlation in the CRN mutant strain was observed only with polyP4. Perhaps this is due to a significant shift in polyphosphate metabolism upon inactivation of the PPN1 gene, in particular, the chain lengthening of inorganic polyphosphates [23]. We observed the same differences in the rhythm of motion of volutin granules in the mutant $\mathrm{CNX}$ strain, in which the PPX1 and PPN1 genes were inactivated, as compared with strains that did not have changes in phosphorus metabolism [15]. Factor analysis in this study showed the presence of a connection for the main factor 1 with all polyphosphate fractions in both the parental CRY strain and the mutant CRN strain. It follows from this that any changes in the processes of synthesis and degradation of inorganic polyphosphates should directly or indirectly lead to the appearance of "dancing bodies". This confirms our early conclusions that the motion of volutin granules due to biological processes and associated with phosphorus metabolism $[14,16]$.

The revealed significant correlation of the "dancing bodies" index with EPPA probably indicates that exopolyphosphatases substantially contribute to the motility of volutin granules. This assumption is supported by the lower "dancing bodies" index in most cases in the mutant CRN strain, noted both in the previous [16] and in this study. Also, as mentioned above, the rhythm of motility of volutin granules of the mutant strain differs significantly from the rhythm of strains in which the entire set of exopolyphosphatases is retained [15]. It is known that a number of enzymes are involved in the polyphosphate metabolism of $S$. cerevisiae: polyphosphate synthase complex Vtc [35], exopolyphosphatase Ppx1 [18], exopolyphosphatase Ppn1 with endopolyphosphatase activity [17], endopolyphosphatase Ppn2 [36], inositol pyrophosphate phosphatase Ddp1 with exopolyphosphatase activity [37] and unidentified vacuolar exopolyphosphatase [38]. The Vtc complex is located on the vacuolar membrane and synthesizes inorganic polyphosphates into the vacuole lumen [39] and consists of five subunits: Vtc4 (catalytic), Vtc1, Vtc2, Vtc3 (structural) [35], and Vtc5 (subsidiary) [40]. Ppx1 is a constitutive enzyme that prefers to hydrolyze short-chain inorganic polyphosphates and is localized in the cytosol, cell wall, and mitochondrial matrix [27]. Ppn1 is an inducible enzyme that is located in the cytosol, nuclei, mitochondrial membranes, and vacuoles. It hydrolyzes mainly high molecular weight inorganic polyphosphates and has exoand endopolyphosphatase catalytic centers [27]. Ppn2 is an endopolyphosphatase localized on the vacuolar membrane [36]. Ddp1 localized in the cytosol and nucleus plays an important role in the metabolism of inositol pyrophosphates and can hydrolyze inorganic polyphosphates in vitro [37]. An unidentified vacuolar exopolyphosphatase was found in a mutant $S$. cerevisiae CNX strain with inactivated $P P X 1$ and $P P N 1$ genes encoding the corresponding polyphosphatases $[27,38]$. Considering the localization of "dancing bodies" in vacuoles, their appearance may participate in polyphosphate synthase complex Vtc, exopolyphosphatase Ppn1 with endopolyphosphatase activity, endopolyphosphatase Ppn2, and unidentified vacuolar exopolyphosphatase. We assume that exopolyphosphatase Ppn1 with endopolyphosphatase activity is one of the key enzymes that influence the motility of volutin granules. It is known that it contributes approximately $70 \%$ of the total vacuolar EPPA in the yeast $S$. cerevisiae [27]. This can explain the low "dancing bodies" index in most cases in the CRN mutant strain, which lacks this exopolyphosphatase. Additional evidence of the contribution of exopolyphosphatases to the motility of volutin granules may be an increase in the number of cells with "dancing bodies" during apoptosis $[12,13]$. It is known that the induction of apoptosis in the human leukemic cell line HL60 by actinomycin $\mathrm{D}$ led to the degradation of long-chain inorganic polyphosphates, caused by an increase of EPPA [28]. Probably, the enzymes of polyphosphate metabolism, in particular exopolyphosphatase, are also activated in yeast vacuoles during the process of programmed cell death.

Earlier, we put forward a hypothesis about the connection of the appearance of "dancing bodies" with the activity of vacuolar exopolyphosphatases [16]. According to our hypothesis, the motility of volutin granules may be a by-product of inorganic polyphosphate cleavage by vacuolar exo- and/or endopolyphosphatases, since there is no data on how exactly the released energy is used during hydrolysis of the high-energy phosphoanhydride bond of these polymers in yeast vacuoles. Perhaps part of this energy dissipates in the form of heat, which is accompanied by the formation of local convection flows, which lead to the movement of the volutin granule. 
Thus, the mobility of volutin granules responds to the changes in polyphosphate metabolism under conditions of normal phosphorus supply of cells, phosphorus starvation, and hypercompensation. Inactivation of the PPN1 gene, which encodes the polyphosphatase Ppn1, leads to a decrease in the "dancing bodies" index. The obtained data indicate a direct connection between the mobility of volutin granules with phosphorus metabolism. However, the determination of the exact cause of "dancing bodies" appearance phenomenon requires further research.

\section{ВПЛИВ ФОСФОРНОГО МЕТАБО- ЛІЗМУ НА РУХЛИВІСТЬ ВОЛЮТИ- НОВИХ ГРАНУЛ SACCHAROMYCES CEREVISIAE}

\section{М.С. Харчук, Е.Н. Громозова}

Інститут мікробіології і вірусології ім. Д.К. Заболотного НАН України, вул. Академіка Заболотного, 154, Київ, 03143, Україна

\section{Резюме}

Відомо, що у вакуолях дріжджів можуть спостерігатися рухливі волютинові гранули (“dancing bodies”), механізм виникнення яких донині залишається малодослідженим. Мета. Виявити наявність зв'язку між рухливістю волютинових гранул Saccharomyces cerevisiae і метаболізмом поліфосфатів в умовах фосфорного голодування і гіперкомпенсації. Методи. У роботі використовували цитологічні, біохімічні та статистичні методи дослідження. Результати. Показано, що кількість клітин $з$ рухливими волютиновими гранулами (показник "dancing bodies") в умовах нормального забезпечення фосфором клітин, фосфорного голодування і гіперкомпенсації у батьківського і мутантного $(\triangle P P N 1)$ штамів відрізнялася. Інактивація гена $P P N 1$, який кодує екзополіфосфатазу Ppn1, призводила до зміни показнику “dancing bodies" в досліджуваних умовах. У мутантного штаму CRN кількість клітин з рухливими волютиновими гранулами майже завжди була нижчою, ніж у батьківського штаму CRY. Зміна загальної кількості неорганічних поліфосфатів в умовах нормального забезпечення фосфором клітин, фосфорного голодування і гіперкомпенсації мала однакову тенденцію для обох штамів. Відмінною рисою було те, що інактивація гена $P P N 1$ призводила до більшого накопичення цих полімерів у мутантного штаму CRN, ніж у батьківського штаму CRY. У обох штамів відмічалась суттєва різниця у профілі поліфосфатних фракцій 1, 2 і 3 (поліФ1, поліФ2 і поліФ3 відповідно). Однак були і загальні риси в динаміці вмісту фракцій цих полімерів. Суттєвих відмінностей у фракціях 4 і 5 (поліФ4 і поліФ5 відповідно) не спостерігалося як у мутантного, так і у батьківського штамів. Встановлено, що в умовах нормального забезпечення фосфором клітин, фосфорного голодування і гіперкомпенсації динаміка загальної екзополіфосфатазної активності (ЕПФА) для обох штамів виявилася майже асинхронною. Відмічено, що показники ЕПФА в деякій мірі мали відповідність до зміни показника "dancing bodies" як для батьківського штаму CRY, так і для мутантного штаму CRN. 3a допомогою лінійного кореляційного аналізу було встановлено, що кількість клітин 3 рухливими волютиновими гранулами у батьківського штаму CRY достовірно корелювала з ЕПФА і вмістом поліФ1, поліФ2 і поліФЗ. В той же час у мутантного штаму CRN показник "dancing bodies" мав достовірний зв'язок з ЕПФА і вмістом поліФ4. За результатами факторного аналізу за методом головних факторів у батьківського штаму CRY за головним фактором 1 найбільш значущі коефіцієнти кореляції спостерігалися між кількістю клітин 3 рухливими волютиновими гранулами і всіма поліфосфатними фракціями. В той же час у мутантного штаму CRN відмічалися значуща кореляція між усіма досліджуваними показниками. За головним фактором 2 у батьківського штаму CRY значущі коефіцієнти були між показниками "dancing bodies”, ЕПФА, вмістом поліФ4 і поліФ5. У мутантного штаму CRN кореляція зі значущими коефіцієнтами спостерігалася між кількістю клітин 3 рухливими волютиновими гранулами, ЕПФА і поліФ4. Висновки. Отримані дані свідчать про прямий зв'язок рухливості волютинових гранул 3 фосфорним метаболізмом в досліджуваних умовах. Припускається, що явище "dancing bodies" може бути наслідком активності вакуолярних поліфосфатаз.

Ключові слова: дріжджі, неорганічні поліфосфати, екзополіфосфатази, “dancing bodies”, волютинові гранули. 
1. Kulaev IS, Vagabov VM, Kulakovskaya TV. [High-molecular-weight inorganic polyphosphates: biochemistry, cell biology, and biotechnology]. Moscow: Nauchnyi Mir; 2005. Russian.

2. Tarayre C, Nguyen H-T, Brognaux A, Delepierre A, De Clercq L, Charlier R, Michels E, Meers E, Delvigne F. Characterization of phosphate accumulation organisms and techniques for polyphosphate detection: a review. Sensors. 2016; 16(6):797-811.

3. Kulaev IS. [Biochemistry of high molecular weight polyphosphates]. Moscow: Moscow State University; 1975. Russian.

4. Allan RA, Miller JJ. Influence of S-adenosylmethionine on DAPI-induced fluorescence of polyphosphate in the yeast vacuole. Can J Microbiol. 1980; 26(8):912-920.

5. Lindegren CC. The origin of volutin on the chromosomes, its transfer to the nucleolus, and suggestions concerning the significance of this phenomenon. Proc Natl Acad Sci USA. 1948; 34(5):187-193.

6. Townsend GF, Lindegren CC. Structures in the yeast cell revealed in a wet mount. Cytologia. 1953; 18(3):183-201.

7. Aswathanarayana NV. The behavior of the vacuole on stimulation of yeast cells with fresh media. Proceedings of the Indian Academy of Sciences - Section B. 1958; 47(4): 225-232.

8. Thyagarajan TR. The reaction of living vegetable cells and zygotes of Saccharomyces carlsbergensis to neutral red. J Indian Instit Sci. 1958; 40(2): 41-49.

9. Barnett JA, Robinow CF. A history of research on yeasts 4: cytology part I, 1890-1950. Yeast. 2002; 19(2):151-82.

10. Puchkov EO. Brownian motion of polyphosphate complexes in yeast vacuoles: characterization by fluorescence microscopy with image analysis. Yeast. 2010; 27(6):309-315.

11. Aswathanarayana NV. The vacuole in yeast. Proceedings of the Indian Academy of Sciences Section B. 1956; 43(6):314-324.

12. Emrick D, Ravichandran A, Gosai J, Gordon DM, Smith $L$ The antifungal occidiofungin triggers an apoptotic mechanism of cell death in yeast. J Nat Prod. 2013; 76(5):829-838.
13. Naito Y, Toh-e A, Hamaguchi H. In vivo time-resolved Raman imaging of a spontaneous death process of a single budding yeast cell. J Raman Spectrosc. 2005; 36(9):837-839.

14. Kharchuk MS, Glushenkov AN, Gromozova EN. Analysis of the motion of vacuolar volutin granules in Saccharomyces cerevisiae. Folia Microbiol. 2019; 64 (2):207-213.

15. Kharchuk MS, Grigoriev PE, Kachur TL, Gromozova EN. [Properties of Saccharomyces cerevisiae volutin granules under conditions of the change of space weather]. Mikrobiol Z. 2016; 78(4):71-81. Russian.

16. Kharchuk MS, Gromozova EN. [The connection of volutin granules motion of Saccharomyces cerevisiae with exopolyphosphatase activity under stress conditions]. Mikrobiol Z. 2018; 80(4):55-68. Russian.

17. Sethuraman A, Rao NN, Kornberg A. The endopolyphosphatase gene: essential in Saccharomyces cerevisiae. Proc Natl Acad Sci USA. 2001; 98(15):8542-8547.

18. Wurst H, Shiba T, Kornberg A. The gene for a major exopolyphosphatase of Saccharomyces cerevisiae. J Bacteriol. 1995; 177(4):898-906.

19. Pestov NA, Kulakovskaya TV, Kulaev IS. Effects of inactivation of the PPN1 gene on exopolyphosphatases and function of mitochondria in the yeast Saccharomyces cerevisiae. FEMS Yeast Res. 2005; 5(9):823-828.

20. Liss E, Langen P. Versuche zur polyphosphat-überkompensation in hefezellen nach phosphatverarmung. Arch Microbiol. 1962; 41(4):383-392.

21. Kulaev IS, Krasheninnikov IA, Kokurina NK. [On the localization of inorganic polyphosphates and nucleotides in Neurospora crassa mycelium]. Biokhimiia. 1966; 31(4): 850-859. Russian.

22. Bradford MM. A rapid and sensitive method for the quantitation of microgram quantities of protein utilizing the principle of protein-dye binding. Anal Biochem. 1976; 72(1-2):248-254.

23. Kulakovskaya TV, Trilisenko LV, Lichko LP, Vagabov VM, Kulaev IS. The effect of inactivation of the exo-and endopolyphosphatase genes PPX1 and PPN1 on the level of different polyphosphates in the yeast Saccharomyces cerevisi- 
ae. Microbiology. 2006; 75(1): 25-28.

24. Hase E, Miyachi S, Mihara S. A preliminary note on the phosphorus compounds in chloroplasts and volutin granules isolated from Chlorella cells. In: Tamiya H, editor. Microalgae and Photosyntetic Bacteria. Tokyo: University of Tokyo Press; 1963. p. 619-626.

25. Friedberg I, Avigad G. Structure containing polyphosphate in Micrococcus lysodeikticus. J Bacteriol. 1968; 96(2):544-553.

26. Kulaev IS, Vagabov VM. Polyphosphate metabolism in microorganisms. Adv Microb Physiol. 1983; 24:83-171.

27. Lichko LP, Kulakovskaya TV, Kulaev IS. Inorganic polyphosphates and exopolyphosphatases in different cell compartments of Saccharomyces cerevisiae. Biochemistry (Mosc). 2006; 71(11):1171-1175.

28. Lorenz B, Münkner J, Oliveira MP, Kuusksalu A, Leitão JM, Müller WEG, Schröder HC. Changes in the metabolism of inorganic polyphosphate in rat tissues and human cells during development and apoptosis. Biochim Biophys Acta. 1997; 1335(1-2):51-60.

29. Imsiecke G, Münkner J, Lorenz B, Bachinski N, Müller WEG, Schröder HC. Inorganic polyphosphates in the developing freshwater sponge Ephydatia muelleri: Effect of stress by polluted waters. Environ Toxicol Chem. 1996; 15(8):1329-1334.

30. Pilatus U, Mayer A, Hildebrandt A. Nuclear polyphosphate as a possible source of energy during the sporulation of Physarum polycephalum. Arch Biochem Biophys. 1989; 275(1):215-223.

31. Ramos I, Gomes F, Koeller CM, Saito K, Heise N, Masuda H, Docampo R, de Souza W, Machado EA, Miranda K. Acidocalcisomes as calcium- and polyphosphate-storage compartments during embryogenesis of the insect Rhodnius prolixus Stahl. PLoS One. 2011; 6(11):e27276.

32. Vagabov VM, Trilisenko LV, Shchipanova IN, Sibel'dina LA, Kulaev IS. [Change in inorganic polyphosphate chain length depending on the stage of Saccharomyces cerevisiae growth]. Mikrobiologiia. 1998; 67(2):188-193. Russian.
33. Kulakovskaya TV, Andreeva NA, Trilisenko LV, Suetin SV, Vagabov VM, Kulaev IS. Accumulation of polyphosphates and expression of high molecular weight exopolyphosphatase in the yeast Saccharomyces cerevisiae. Biochemistry (Mosc). 2005; 70 (9):980-985.

34. Vagabov VM, Trilisenko LV, Kulakovskaya TV, Kulaev IS. Effect of a carbon source on polyphosphate accumulation in Saccharomyces cerevisiae. FEMS Yeast Res. 2008; 8(6):877-882.

35. Hothorn M, Neumann H, Lenherr ED, Wehner M, Rybin V, Hassa PO, Uttenweiler A, Reinhardt M, Schmidt A, Seiler J, Ladurner AG, Herrmann C, Scheffzek K, Mayer A. Catalytic core of a membrane-associated eukaryotic polyphosphate polymerase. Science. 2009; 324(5926):513-516.

36. Gerasimaite R, Mayer A. Ppn2, a novel Zn2+dependent polyphosphatase in the acidocalcisome-like yeast vacuole. J Cell Sci. 2017; 130(9):1625-1636.

37. Lonetti A, Szijgyarto Z, Bosch D, Loss O, Azevedo C, Saiardi A. Identification of an evolutionarily conserved family of inorganic polyphosphate endopolyphosphatases. J Biol Chem. 2011; 286(37):31966-31974.

38. Lichko LP, Kulakovskaya TV, Kulaev IS. Inactivation of endopolyphosphatase gene PPN1 results in inhibition of expression of exopolyphosphatase PPX1 and high-molecular-mass exopolyphosphatase not encoded by PPX1 in Saccharomyces cerevisiae. Biochim Biophys Acta. 2004; 1674(1):98-102.

39. Gerasimaitè R, Sharma S, Desfougeres Y, Schmidt A, Mayer A. Coupled synthesis and translocation restrains polyphosphate to acidocalcisome-like vacuoles and prevents its toxicity. J Cell Sci. 2014; 127(Pt 23):5093-5104.

40. Desfougères Y, Gerasimaitè RU, Jessen HJ, Mayer A. Vtc5, a novel subunit of the vacuolar transporter chaperone complex, regulates polyphosphate synthesis and phosphate homeostasis in yeast. J Biol Chem. 2016; 291(42): 22262 22275.

Received 3.03.2021 